\title{
Precipitation of carbonates by bacteria isolated from wastewater samples collected in a conventional wastewater treatment plant
}

\author{
A. Rivadeneyra Torres • M. V. Martinez-Toledo • \\ A. Gonzalez-Martinez • J. Gonzalez-Lopez • \\ D. Martín-Ramos • M. A. Rivadeneyra
}

Received: 10 November 2011/Accepted: 16 June 2012/Published online: 11 July 2012

(c) CEERS, IAU 2012

\begin{abstract}
This research studied the precipitation of calcium carbonate by populations of bacteria from domestic wastewater cultivated in both natural and artificial solid culture media. The only carbonate-forming bacteria detected appeared in an artificial medium added with calcium acetate. Precipitation occurred three days after inoculation, and the percentage was slightly higher than $65 \%$.
\end{abstract}

\footnotetext{
A. Rivadeneyra Torres $(\bowtie)$

Departamento de Electrónica y Tecnología de Computadores, Escuela Técnica Superior de Ingenierías Informática y de Telecomunicación, Universidad de Granada, Campus Universitario de Almanjayar, 18071 Granada, Spain e-mail: arivadeneyra@ugr.es

\section{V. Martinez-Toledo}

Departamento de Microbiología, Facultad de Ciencias, Universidad de Granada, Campus Universitario de Fuentenueva, 18071 Granada, Spain

e-mail: mvmt@ugr.es
}

\section{A. Gonzalez-Martinez}

Departamento de Ingeniería Civil, ETS Ingenieros de Caminos Canales y Puertos, Universidad de Granada,

Campus de Fuentenueva, 18071 Granada, Spain

e-mail: agon@ugr.es

\section{J. Gonzalez-Lopez · M. A. Rivadeneyra}

Departamento de Microbiología, Facultad de Farmacia, Universidad de Granada, Campus Universitario de Cartuja, 18071 Granada, Spain

e-mail: jgl@ugr.es

M. A. Rivadeneyra

e-mail: mrivaden@ugr.es

\section{Martín-Ramos}

Departamento de Mineralogía y Petrología, Facultad de Ciencias, Universidad de Granada, Campus Universitario de Fuentenueva, 18071 Granada, Spain

e-mail: jdmartin@ugr.es
Our results showed that nine major carbonate-forming colony types were the dominant heterotrophic platable bacteria growing aerobically in artificial media added with calcium acetate. According to their taxonomic affiliations (based on partial sequencing of the 16S-rRNA), the nine strains belonged to the following nine genera of Gramnegative and Gram-positive bacteria: Caulobacter, Blastomonas, Roseobacter, Staphylococcus, Bacillus, Gemmatimonas, Saccharopolyspora, Microthrix, and Sphingomonas. All of these strains formed calcium carbonate, precipitated as calcite and vaterite in different proportions and shapes (spheres, hemispheres, dumbbells, and pseudopolyhedral forms). The results of this study suggest that in real domestic wastewater, the precipitation of carbonates through bacterial action could not take place in situ because the concentrations of calcium did not create the optimal circumstances for biomineralization. However, in the artificial media, it was possible to induce this process by adding calcium ions.

Keywords Calcite $\cdot$ Calcium carbonate $\cdot$ Domestic wastewater - Vaterite

\section{Introduction}

Calcium carbonate precipitation is a common phenomenon found in different environments, such as sea water, freshwater, industrial wastewaters, and soil (Delgado et al. 2008; Ehrlich 2002; Hammes and Verstraete 2002; Hammes et al. 2003). It is a chemical process that requires sufficient calcium concentration and carbonate ions so that the ion activity product exceeds the solubility constant. It also depends on the presence of nucleation sites. 
Microorganisms, mainly bacteria, contribute to the precipitation of a wide variety of minerals (Dove et al. 2003; Ehrlich 2002). Numerous laboratory studies have demonstrated the bacterial precipitation of carbonates (Rivadeneyra et al. 1999; Rivadeneyra et al. 2000, 2006a, b; Sánchez-Román et al. 2007) and have proposed different mechanisms for the bacterially mediated precipitation of carbonate minerals (Ehrlich 2002; Rivadeneyra et al. 1998; Rivadeneyra et al. 2010; van Lith et al. 2003). One of the mechanisms most often proposed is the production of ammonium and $\mathrm{CO}_{2}$ by microorganisms (which increases the $\mathrm{pH}$ ) in the presence of calcium and magnesium-produced calcium or calcium and/or magnesium carbonates. This is an induced precipitation mechanism (Lowenstam and Weiner 1989), where the metabolic activity alters the physicochemical parameters of the habitats of these microorganisms, allowing the precipitation of minerals. Other authors have reported that the bacteria can serve as a nucleus for mineral precipitation upon adsorbing $\mathrm{Ca}^{2+}, \mathrm{Mg}^{2+}$ and other metallic cations onto the cell surface, and that the matrix of extracellular polymeric secretions affects mineral precipitation (Beveridge and Fyfe 1985; Rivadeneyra et al. 2006a; van Lith et al. 2003). In this context, the role of bacterial surfaces in the nucleation of certain minerals (such as some types of carbonate) has been widely discussed. However, in many cases, the exact role of the bacteria in such nucleation remains unclear.

Different bacterial species have previously been detected and assumed to be associated with carbonate precipitation in diverse environments including bioreactor systems for industrial wastewater treatments (Hammes et al. 2003; van Lith et al. 2003). Species-specific carbonate precipitation has been hypothesized by several authors (Hammes and Verstraete 2002) though the exact mechanisms of precipitation and the way that this process works within the microbial ecology of the precipitating organism remains unresolved.

The activated sludge process is a wastewater treatment method in which the carbonaceous organic matter of wastewater provides an energy source for the production of new cells for a mixed population of microorganisms in an aquatic aerobic environment. The microbes convert carbon into cell tissue and oxidized end products that include carbon dioxide and water. The majority of microorganisms in activated sludge are bacteria. For the most part, they are heterotrophic, and thus require organic compounds for their supply of carbon and energy. In contrast, autotrophic bacteria, which use inorganic compounds for cell growth, occur in proportion to concentrations of carbon and nitrogen. Important genera of heterotrophic bacteria include Achromobacter, Sphingomonas, Alcaligenes, Arthrobacter, Citromonas, Flavobacterium, Pseudomonas, and Zoogloea
(Jenkins et al. 1993). Previous studies have shown that microbial populations influence the precipitation of different minerals in wastewater treatment systems (Dove et al. 2003; Hammes et al. 2003). For example, the interest in dedicated reactors for struvite precipitation is currently growing because of the extensive operational problems caused by struvite accumulation in wastewater treatment plants (Straful et al. 2001).

In this paper, we study carbonate precipitation by bacteria isolated from domestic wastewater collected from the municipal wastewater treatment plant of the city of Granada (Puente de los Vados, Granada, Spain) in culture media made from domestic wastewater (natural media) and in artificial culture media (conventional media for carbonate precipitation). The main goal was to demonstrate which culture conditions influence carbonate formation caused by bacteria isolated from real domestic wastewater. This paper also discusses the relation of these microorganisms to biomineralization in culture media.

\section{Materials and methods}

\section{Domestic wastewater samples}

Wastewater samples were collected from the wastewater treatment plant of the city of Granada (Puente de los Vados, Granada), operated by EMASAGRA S.A. This wastewater was taken from the primary settling tank of the treatment plant. The average composition of wastewater was determined by standard methods (Clesceri et al. 2001) and was found to be the following: chemical oxygen demand (COD), $450 \mathrm{mg} / \mathrm{l}$; biological oxygen demand at 5 days (BOD5), $300 \mathrm{mg} / \mathrm{l} ; \mathrm{NO}_{3}, 5 \mathrm{mg} / \mathrm{l} ; \mathrm{NH}_{4}, 75 \mathrm{mg} / \mathrm{l}$; $\mathrm{Ca}^{2+}, 15 \mathrm{mg} / \mathrm{l}$; total suspended solids (TSS), $0.01 \mathrm{~g} / \mathrm{l}$; volatile suspended solids (VSS), $0.78 \mathrm{~g} / \mathrm{l}$. The samples were collected in sterile bottles $(1 \mathrm{~L})$, shipped to the laboratory, and refrigerated $\left(4^{\circ} \mathrm{C}\right)$ until their analysis in the laboratory.

\section{Culture media}

The culture media used in this study were wastewater media (WWM) and artificial media added with calcium acetate (MC). The WWM medium was composed of domestic wastewater with the addition of $18 \mathrm{~g} / \mathrm{l}$ of BactoAgar. The $\mathrm{pH}$ of the medium was adjusted to 7.2 with $0.1 \mathrm{M} \mathrm{KOH}$. The MC medium was composed of $10.0 \mathrm{~g} / \mathrm{l}$ yeast extract, $5.0 \mathrm{~g} / 1$ protease peptone, $1.0 \mathrm{~g} / \mathrm{l}$ glucose, and $4.0 \mathrm{~g} / \mathrm{l}$ calcium acetate. To obtain a solid medium, $18 \mathrm{~g} / \mathrm{l}$ Bacto-Agar was added, and the $\mathrm{pH}$ was adjusted to 7.2 with $0.1 \mathrm{M} \mathrm{KOH}$. The culture media were autoclaved at $112{ }^{\circ} \mathrm{C}$ for $20 \mathrm{~min}$. 


\section{Microorganisms}

The experiments were performed with bacterial strains isolated from urban wastewater samples. Aliquots $(0.1 \mathrm{ml})$ of the wastewater samples were serially diluted and spread on plates containing WWM and MC solid media. Plates were aerobically incubated at $25^{\circ} \mathrm{C}$ for 30 days and checked periodically for the presence of crystals using optical microscopy. The percentage of crystal-forming and non-crystal-forming colonies was counted. Isolated representatives of the dominant colony morphologies with crystal-forming capacity were selected and purified, by restreaking them twice on trypticase soy agar (TSA). All the experiments were carried out in triplicate.

Genetic identification of the isolated bacterial strains

In this study, all of the strains isolated (with crystalforming capacity) were identified by analyzing the partial sequence of the gene encoding 16S rRNA. Primers fD1 and rD1 (Weisburg et al. 1991) were synthesized by Sigma Genosis (UK) and used to amplify nearly the full length of the 16S rRNA gene. Fresh cultured colonies of each strain were lysed by the addition of $20 \mu \mathrm{l}$ of a mixture of $\mathrm{NaOH}$ $(0.05 \mathrm{M})-\mathrm{SDS}(0.25 \%$, w/v), which was then boiled for $15 \mathrm{~min}$. The lysates were adjusted to $200 \mu \mathrm{l}$ with sterile water and centrifuged at $2500 \mathrm{~g}$ for $5 \mathrm{~min}$ in a table-top centrifuge. The cleared lysates $(4 \mu \mathrm{l})$ were used as a template for amplification. PCR was carried out by adding the following to the lysates: 1xPCR Gold buffer (Applied Biosystems, Germany); $1.5 \mathrm{mM} \mathrm{MgCl} 2$ (Applied Biosystems, Germany); $200 \mu \mathrm{M}$ dNTPs (Roche Molecular Biochemicals, Germany); 20 pmol of each primer; and $1 \mathrm{U}$ of Ampli-Tag Gold polymerase (Applied Biosystems, Germany). The final volume of the reaction tubes was adjusted to $50 \mu \mathrm{l}$. Reactions were run in a Perkin Elmer GeneAmp PCR system 2400 (Perkin Elmer, Norwalk, CT, USA). The temperature profile was the one previously described by Vinuesa et al. (1998), except for the extension of the initial denaturation step to $7 \mathrm{~min}$, as required, using the Quiaex II kit (Qiagen, Germany). The nucleotide sequence of the purified bands was determined by the dideoxy chain terminator method, using the ABI-PRISM Big Dye Terminator Cycle Sequencing Ready Reaction kit (Perkin Elmer, Norwalk, CT, USA) and automated sequencer ABI-PRISM 3100 Avant Genetic Analyzer (Applied Biosystems, Germany). The sequenced fragment analyzed corresponded to the first $650 \mathrm{bp}$ of the 16S-rRNA gene, comprising hypervariable regions V1, V2, and V3 (Neefs et al. 1990).

DNA sequences were analyzed using the biocomputing tools provided on-line by the European Bioinformatics Institute (http://www.ebi.ac.uk). The BLASTn (Altschul et al. 1997) program was used for preliminary sequence similarity analysis, and the ClustalX v.1.8 software (Jeanmougin et al. 1998) was used for sequence alignment.

Study of mineral formation

All the nine strains (major colony types) isolated from the wastewater samples with crystal-forming capacity were surface-inoculated onto WWM and MC solid media, incubated aerobically at $25{ }^{\circ} \mathrm{C}$, and periodically examined with an optical microscope for the presence of carbonate crystals up to 30 days after inoculation. The experiments were carried out in triplicate and were repeated three times. A control consisting of uninoculated culture media and media inoculated with autoclaved bacterial cells were included in all experiments.

For mineralogical and morphological analysis, precipitates were removed by cutting out pieces of the media, which were placed in boiling water to dissolve the agar. The sediments were re-suspended and washed in distilled water to free them of impurities. In this treatment, calcium carbonate dissolution was not significant, and the morphology of crystals was not altered, as observed by optical microscopy both before and after their recovery. The washed carbonate crystals were finally air-dried at $37{ }^{\circ} \mathrm{C}$.

\section{XRD study}

The precipitates obtained after 30 days of incubation were examined by powder X-ray diffraction (PXRD) using a Philips PW 1710/00 diffractometer, with a graphite monochromator automatic slit, $\mathrm{CuK} \alpha$ radiation, and on-line connection with microcomputer. Data were collected for a $0.4 \mathrm{~s}$ integration time in $0.02{ }^{\circ} \mathrm{C} 2 \theta$ steps at $40 \mathrm{kV}$ and $40 \mathrm{~mA}$, in a $2 \theta$ interval between 3 and $80{ }^{\circ} \mathrm{C}$. Data were processed using the XPPowder program for a qualitative and quantitative determination of the mineral composition (Martín 2004). The crystalline mosaic size on hkl reciprocal vectors was obtained from full width at half of the maximum intensity (FWHM) after instrumental broadening and $K_{\alpha 2}$ corrections.

\section{SEM study}

Secondary electron micrographs of bacterial precipitates were made with gold-coated samples using a Zeiss DMS SEM (LEO Electron Microscopy, Oberkochen, Germany), operated at an acceleration voltage of $20 \mathrm{kV}$ to examine the micromorphology of the crystals. Some selected samples were coated with carbon for energy dispersive X-ray (EDX) microanalysis. High-resolution secondary electron images were prepared with a field emission scanning electron microscopy (FESEM) LEO 1525, under 2-3 kV on carbon-coated samples. 


\section{Results and discussion}

The formation of calcium carbonate was only observed in artificial media (MC). No precipitation was detected in natural media (WWM), uninoculated control media, or media inoculated with a high concentration of dead bacteria and thus without metabolic activity. The number of bacteria (CFU) per ml of urban wastewater recounts in WWM medium was $5.5 \times 10^{5}$, whereas in MC medium, it was $2.3 \times 10^{6}$. The percentage of carbonate-forming bacteria in the MC medium was slightly higher than $65 \%$. Precipitation took place rapidly, and crystal formation began 3 days after inoculation. After 10 days, the crystals had significantly increased in quantity and were of a large size. Figure 1 shows colonies with precipitates of carbonates.

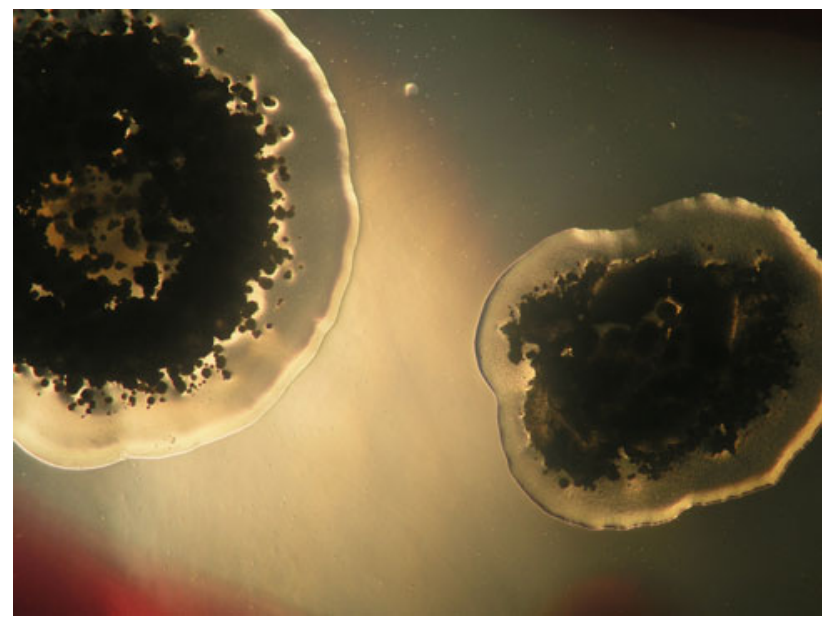

Fig. 1 Colonies with precipitates of carbonates
Nine major colony types were detected as the dominant heterotrophic platable bacteria growing aerobically in MC media. Nine different colonies of identical morphology were randomly selected from plates, re-isolated, and tested for phenotypical characters. Identical results were obtained. The taxonomic affiliations of the nine strains, based on partial sequencing of the 16S-rRNA gene (V1 to V3 hypervariable regions, ca. $650 \mathrm{nt}$ ) are shown in Table 1. The strains fell into eight different genera of Gram-negative and Gram-positive bacteria. Sequence comparison with databases demonstrated the affiliation of strain WW1 to Caulobacter sp. (95.8\% identity), WW2 to Blastomonas sp. (99.7\% identity), WW3 to Roseobacter sp. (89.4\% identity), WW4 to Staphylococcus epidermidis (100\% identity), WW5 to Bacillus cereus (98.8 \% identity), WW6 to Gemmatimonas aurantica ( $89.4 \%$ identity), WW7 to Saccharopolyspora sp. (82.3\% identity), WW8 to Microthrix parvicella (96.9\% identity) and WW9 to Sphingomonas sp. (99.4\% identity).

The results of the mineralogical analysis with XRD (Fig. 2; Table 2) showed that all of the strains formed calcium carbonate, precipitated as calcite and vaterite in different proportions, depending on the strain. Precipitation of small amounts of calcium phosphates and different percentages of amorphous crystals were also observed in all cases (Fig. 1).

WW7 and WW8 strains affiliated as Actinobacteria precipitated minerals with a low percentage of calcite and a high percentage of vaterite of lower crystallinity than the precipitated mineral produced by bacterial strains affiliated to other taxonomic classes. These results were also verified by measuring the crystal size of all the samples (Table 2).

Table 1 Identification of strains with crystal-forming capacity isolated from urban waste waters

\begin{tabular}{|c|c|c|c|c|c|}
\hline Strain & Closest taxonomy affiliation (class/family) & Overlap (nt) & Most similar organisms & Access nc. & Percent identity \\
\hline \multirow[t]{2}{*}{ WW1 } & \multirow[t]{2}{*}{$\alpha$-proteobacteria/Caulobacteraceae } & \multirow[t]{2}{*}{120} & Caulobacter sp. 5142 & AY97383 & 95.8 \\
\hline & & & Brevundimonas sp. K2/98-FUNDUS & AJ313427 & 90.2 \\
\hline \multirow[t]{2}{*}{ WW2 } & \multirow[t]{2}{*}{$\alpha$-proteobacteria/Sphingomonadaceae } & \multirow[t]{2}{*}{123} & Blastomonas sp. & AB242676 & 99.7 \\
\hline & & & Sphingomonas sp. & AJ812013 & 98.1 \\
\hline \multirow[t]{2}{*}{ WW3 } & \multirow[t]{2}{*}{$\alpha$-proteobacteria/ } & \multirow[t]{2}{*}{123} & Roseobacter sp. & AY136130 & 89.4 \\
\hline & & & Sinorickettsia chlamys & AY174894 & 86.1 \\
\hline WW4 & Bacilli/Staphylococcoae & 159 & Staphylococcus epidermidis & AF270147 & 100 \\
\hline \multirow[t]{2}{*}{ WW5 } & \multirow[t]{2}{*}{ Bacilli/Bacillaceae } & \multirow[t]{2}{*}{141} & Bacillus cereus & AY138274 & 98.8 \\
\hline & & & Bacillus anthracis & AY138291 & 81.4 \\
\hline \multirow[t]{2}{*}{ WW6 } & \multirow[t]{2}{*}{ Gammatimonadetes } & \multirow[t]{2}{*}{159} & Gemmatimonas aurantiaca & AB072735 & 89.4 \\
\hline & & & Bacterium Ellin 5290 & AY234641 & 86.3 \\
\hline WW7 & Actinobacteria/Pseudonocarficceae & 141 & Saccharopolyspora sp. & H7131491 & 82.3 \\
\hline \multirow[t]{2}{*}{ WW8 } & \multirow[t]{2}{*}{ Actinobacteria } & \multirow[t]{2}{*}{124} & Microthrix parvicella & X93044 & 96.4 \\
\hline & & & Collinsella sp. & AB064936 & 82.7 \\
\hline \multirow[t]{2}{*}{ WW9 } & \multirow[t]{2}{*}{$\alpha$-proteobacteria/Sphingomonadaceae } & \multirow[t]{2}{*}{123} & Sphingomonas sp. & AJ812013 & 99.4 \\
\hline & & & Blastomonas sp. & AB242676 & 91.2 \\
\hline
\end{tabular}




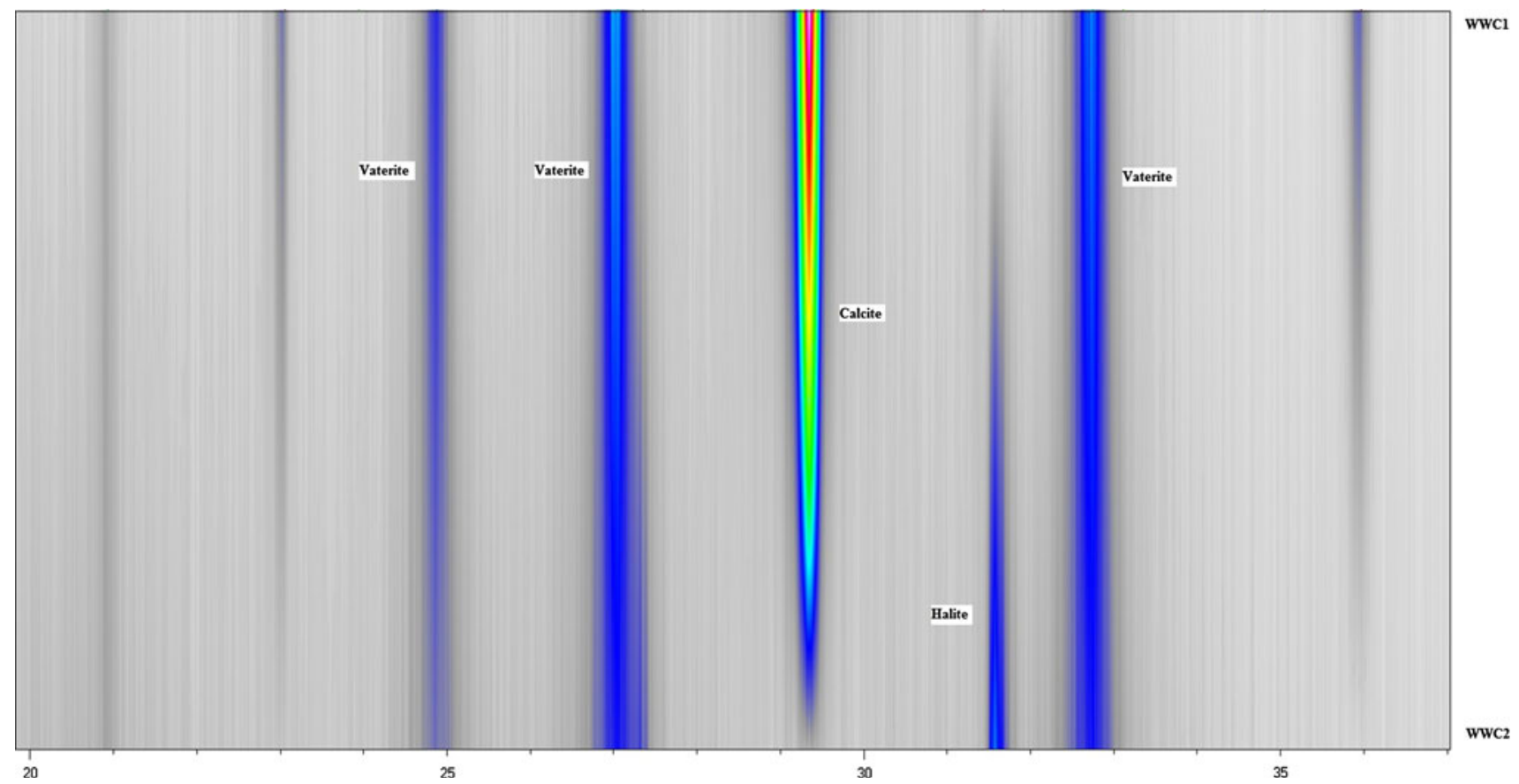

Fig. 2 Map drawn from XRD patterns. Colors in the map indicate the changing intensity of the diffracted X-rays as a function of $2 \theta$, with warmer colors for progressively higher intensities. Residues of halite of the culture media are also present in the patterns

Table 2 Quantitative analysis of precipitates and size of crystal

\begin{tabular}{|c|c|c|c|c|c|}
\hline \multirow[t]{2}{*}{ Bacteria } & \multicolumn{2}{|l|}{ Vaterite } & \multicolumn{2}{|l|}{ Calcite } & \multirow{2}{*}{$\begin{array}{l}\mathrm{Ca} \\
\text { phosphates }+ \text { amorphous } \\
\% \text { Crystalline components }\end{array}$} \\
\hline & $\begin{array}{l}\% \text { Crystalline } \\
\text { components }\end{array}$ & $\begin{array}{l}\text { Crystal size } \\
(\mathrm{nm})\end{array}$ & $\begin{array}{l}\text { \% Crystalline } \\
\text { components }\end{array}$ & Crystal size (nm) & \\
\hline Actinomycetes & $72.5 \pm 4.25$ & $20 \pm 1$ & $8.3 \pm 0.8$ & $\begin{array}{l}\text { Very low, Shortly } \\
\text { content }\end{array}$ & $19.2 \pm 1.7$ \\
\hline Other bacteria & $42.2 \pm 4.3$ & $29 \pm 4.6$ & $52.8 \pm 8.9$ & $50 \pm 6.5$ & $5 \pm 4.5$ \\
\hline
\end{tabular}

In general, it was observed that the calcite showed higher crystallinity than the vaterite. In contrast, the vaterites precipitated by Actinobacteria showed a lower crystallinity than the vaterites precipitated by the other microorganisms studied. Moreover, in the minerals precipitated by Actinobacteria, a high percentage of amorphous forms was also observed.

A variety of shapes were observed by SEM (Figs. 3, 4). Of these, the most important were spheres, hemispheres, dumbbells, and pseudopolyhedral forms, which appeared either in isolation or in groups. However, spherulitic forms were also predominant. Certain differences were detected in the spherulites produced by Actinobacteria strains and the spherulites formed by the rest of the microorganisms. More specifically, the spherulites formed by non-Actinobacteria microorganisms had rough surfaces with small holes, and high porosity (Fig. 3a). Many holes were of bacteria-like size and shape, and in many cases, mineralized bacteria were clearly evident (Fig. 3b, c, d). However, most of the bioliths generated by Actinobacteria were formed by cell aggregation strains. Other spherulites did not show any cell mark, but rather were frequently covered by mineralized filaments (Fig. 4). The microscopical observation of the plates showed that the majority of spherulites were not only in the bacterial mass but also near the colonies. The EDX analysis (Fig. 5) confirmed the DRX results and showed that spherulites formed by Actinobacteria had a greater concentration of phosphates than the spherulites precipitated by other bacteria. The analysis also showed that the calcified filament in some Actinobacteria spherulites contained a greater proportion of calcium phosphate than the rest of the spherulites.

The influence of microorganisms in mineral precipitation has been recognized for a wide variety of minerals. In 

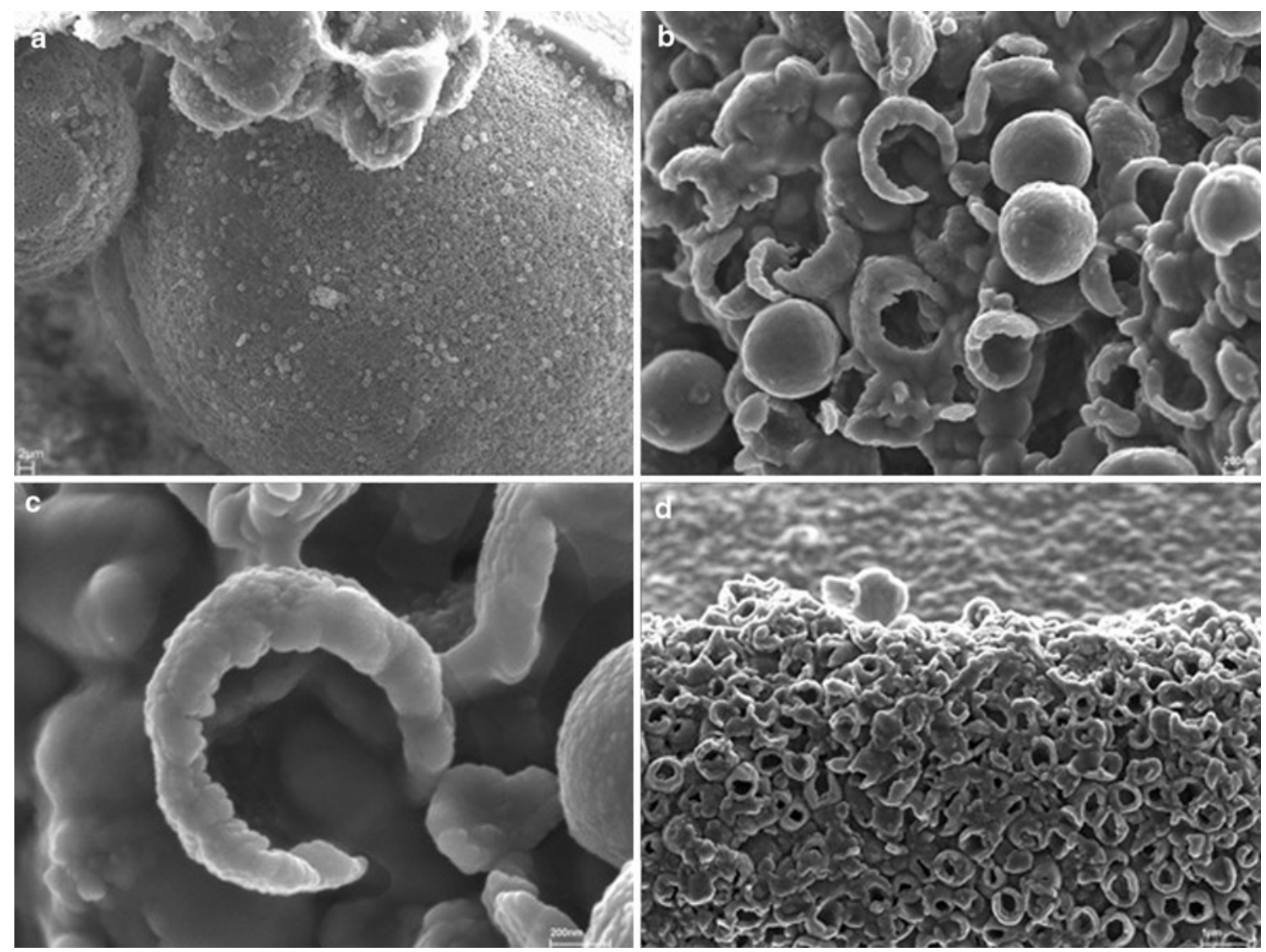

Fig. 3 SEM and FESEM images of carbonate bioliths formed by WW4 strain (Staphylococcus epidermidis). a Spherulites and dumbbells. b, c Close-up of the boxed area in a, showing a dense aggregate of mineralized bacterial cells composed of Ca-carbonate. Note the

abundance of calcium-carbonate nanoparticles delimiting the bacterial-cell contours. d Edge of a hemispherical biolith (hemispheres) which shows its formation by accumulation of calcified coccos

fact, there have been various research studies on microbial involvement in carbonate precipitation in natural environments (Ehrlich 2002; Parraga et al. 2004). Generally speaking, calcium carbonate biomineralization is not necessarily linked to any particular group of microorganisms, and has been extensively documented in a variety of natural environments.

A culture-dependent approach was used to analyze the widely diverse bacteria in the urban wastewater of our study. The results showed a complex cultivable community mainly integrated by members of the genus Caulobacter, Blastomonas, Roseobacter, Staphylococcus, Bacillus, Gemmatimonas, Saccharopolyspora, and Collinsella. This technique has been extensively applied to the study of a variety of different bacterial ecosystems, including wastewaters, sludges, and biofilms. However, recently, the introduction of molecular biology techniques based on the in situ detection of nucleic acids has provided important information about microorganisms in their natural habitats. In this context, denaturing gradient gel electrophoresis (DGGE/TGGE) yields extensive data concerning the complexity and behavior of microbial communities

(Muyzer 1999). Most of these techniques have been used in recent studies on the ecology of biological processes in wastewaters (Wagner et al. 2002). We found that the community isolated in our standard domestic wastewater using culture-dependent methods was analogous to what has been described by other authors using culture-independent techniques, such as DGGE and TGGE (CortesLorenzo et al. 2006; Molina-Muñoz et al. 2007).

Numerous laboratory studies and observations in natural environments have demonstrated the bacterial precipitation of calcium carbonate (Rivadeneyra et al. 1999, 2000, 2006b; Sánchez-Román et al. 2007). One of the mechanisms of calcium carbonate precipitation most often proposed is that microorganisms produce $\mathrm{NH}_{4}{ }^{+}$by metabolizing nitrogenated organic substrates, which increase the $\mathrm{pH}$. In the presence of calcium ions, the $\mathrm{CO}_{2}$ also produced by the bacterial activity precipitates at a basic $\mathrm{pH}$ in the form of calcite, aragonite, vaterite, etc. Consequently, the $\mathrm{CO}_{2}$ produced by the microbial community during the biodegradation of the organic matter is totally or partially used for the formation of calcium carbonate. 

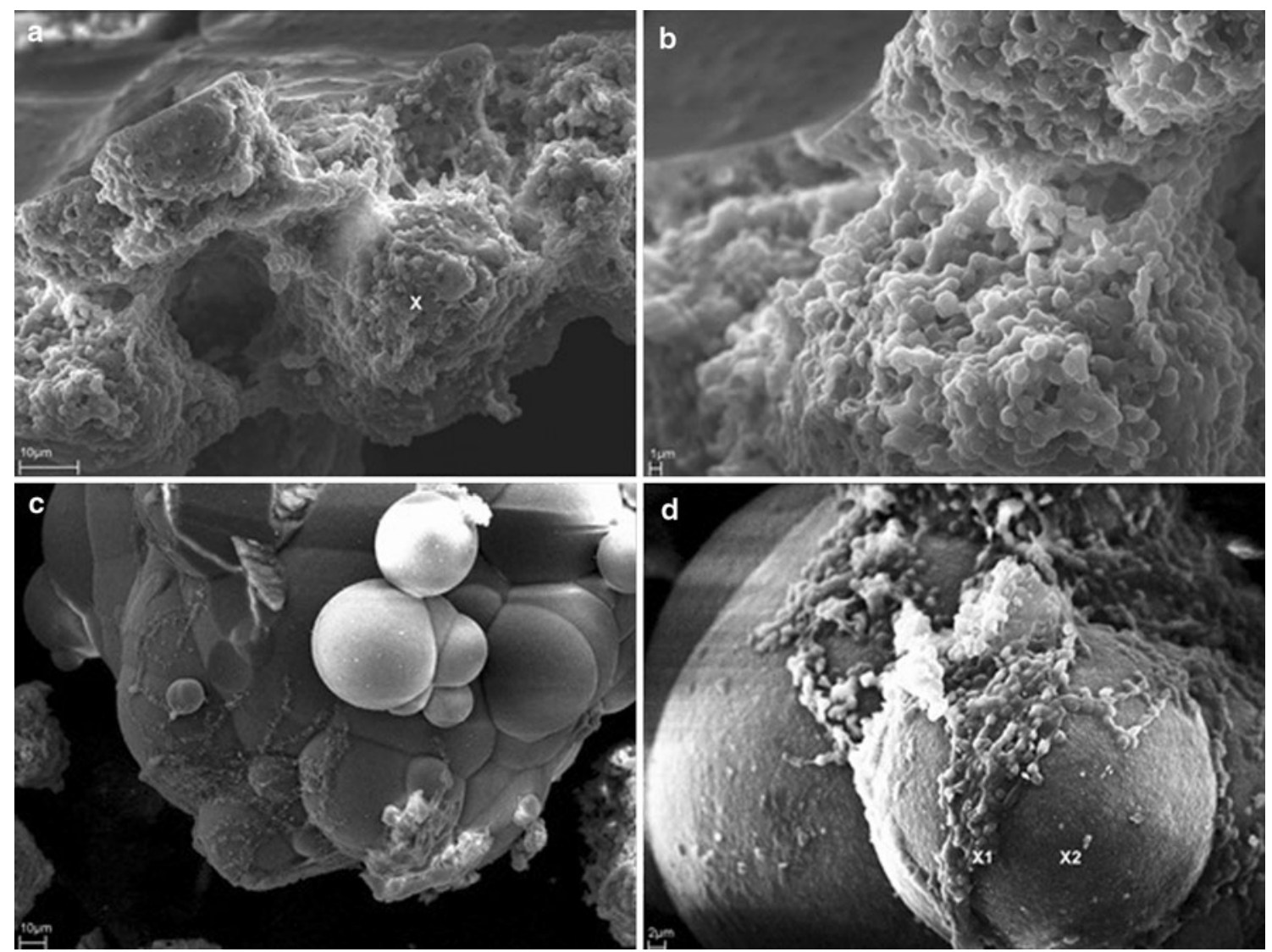

Fig. 4 SEM images of carbonate bioliths formed by actinobacteria strains WW7 (Saccharopolyspora $s p$ ) and WW8 (Microthrix parvicella) (a) and (b) Spherulites in formation, showing a dense aggregate of mineralized bacterial cells composed principally of Ca-carbonate

To date, most systematic studies on bacterial calcium carbonate biomineralization have been carried out in natural aquatic environments (many of which are marine environments) or in artificial culture media using different microorganisms previously isolated from aquatic or soil habitats (Delgado et al. 2008; Parraga et al. 2004; Rivadeneyra et al. 2006a, b). Nevertheless, there have been no publications that have reported the bioprecipitation of calcium carbonate associated with a microbial community in domestic wastewaters.

Our study did not detect the formation of calcium carbonate when bacterial colonies were grown in a natural culture medium containing urban wastewater as a source of nutrients (WWM medium). In the case of the WWM medium, all of the bacterial strains grew there very well, and formed colonies in $48 \mathrm{~h}$ though no crystal formation was observed after the 30-day incubation period. In contrast, $65 \%$ of the colonies detected in the artificial culture media, containing yeast extract, protease peptone, glucose, and calcium acetate, formed calcium carbonate after an incubation period of 3 days. Previous results have shown that calcium and metabolizable organic substrate

(see EDX spectrum b). c, d spherulites group with smooth surface, where they are not observed traces of bacteria. Some spherulites are covered by mineralized filaments EDX spectrum indicates that they are composed of $\mathrm{Ca}$ and $\mathrm{P}$

concentrations are influential factors in the biomineralization of calcium carbonate (Delgado et al. 2008). Our data suggest that the calcium concentration in the urban wastewaters was not sufficient to produce the precipitation of calcium carbonate under our experimental conditions. However, in artificial culture media amended with high concentrations of metabolizable organic matter and significant amounts of calcium, the microbial populations in the urban wastewaters were able to create the optimal conditions for the formation of carbonates.

The most significant finding of this research study is that bacterial populations in domestic wastewater can precipitate calcium carbonate in the form of calcite and vaterite in different proportions, depending on the strain. Moreover, the precipitation of small amounts of calcium phosphates and different percentages of amorphous crystals can also be produced in all cases. However, this precipitation capacity was only induced when the microorganisms were cultivated in artificial laboratory media and never when the microorganisms were cultivated in natural media derived from the wastewater. This suggests that in actual domestic wastewater, the precipitation of carbonates through 
Fig. 5 EDX spectra of carbonate bioliths (a) carbonate bioliths formed by WW4 strain (See location in Fig. 3a). Bioliths formed by actinobacteria strains: b bioliths in formation (See location in Fig. 4a), c spherulites group with smooth surface (See location in Fig. 4d) and d mineralized filaments covering some spherulites (See location in Fig. 4d)

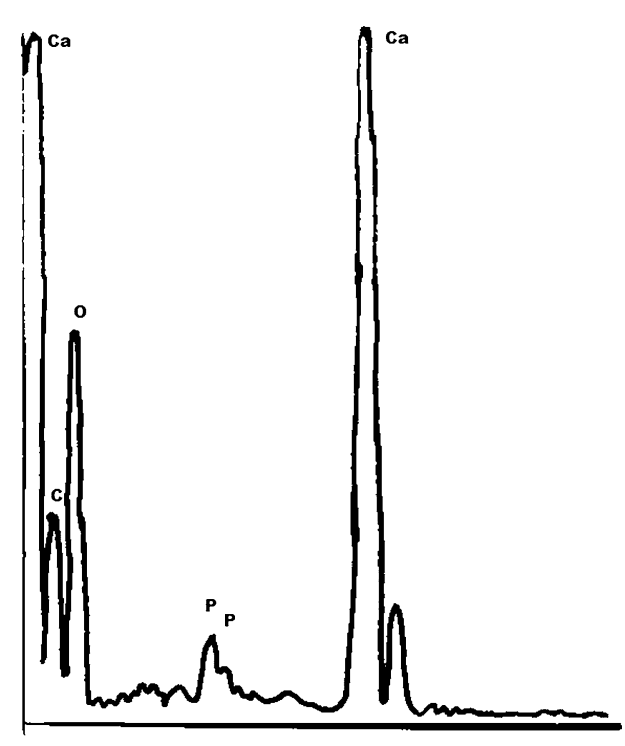

a
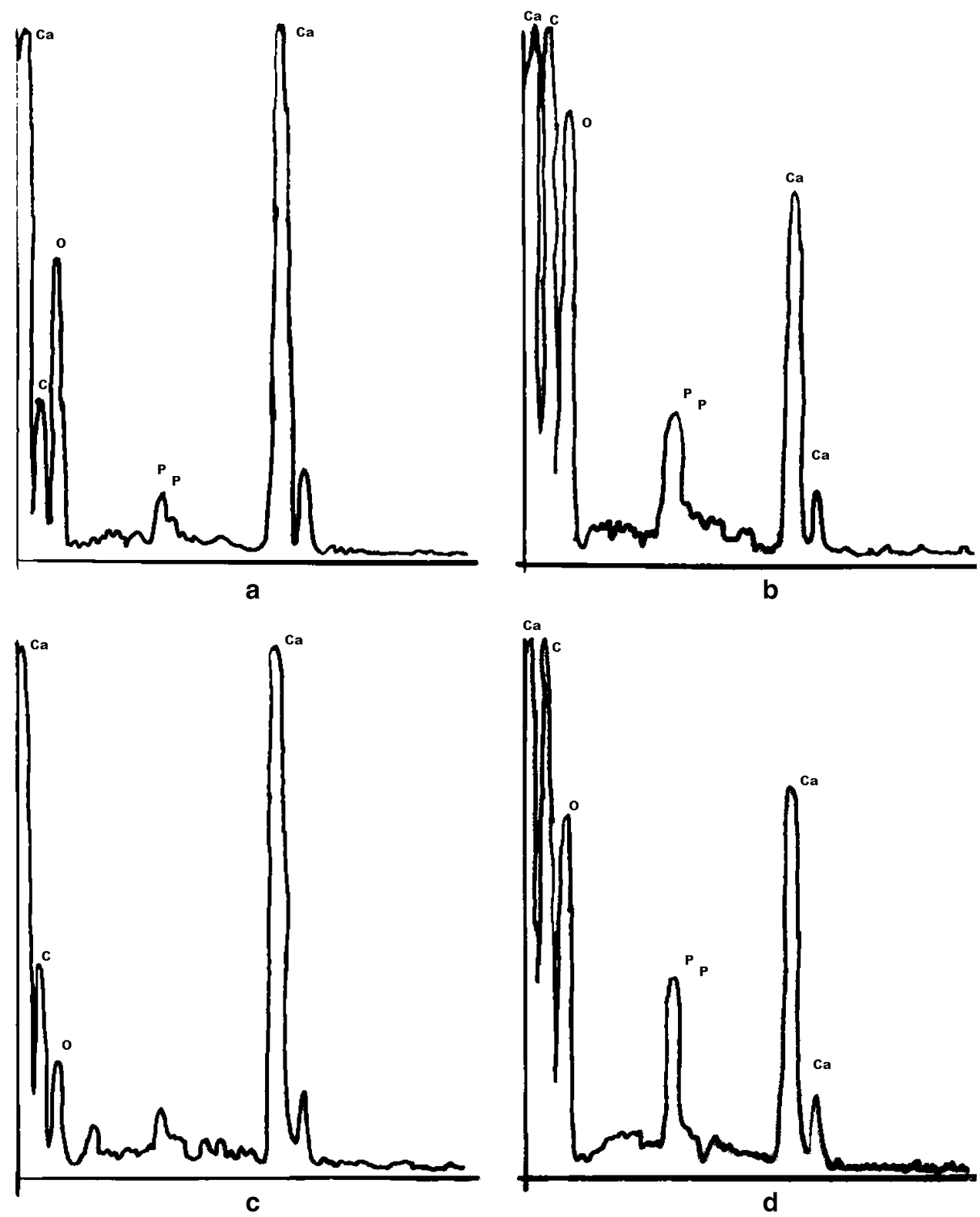

bacterial action could not take place in situ. Obviously, the chemical composition of the wastewater can affect the result of the process. If the wastewater had a high concentration of calcium, then the biomineralization of calcium carbonate could be bacterially induced.

SEM was used to detect a wide range of morphological features and shapes (i.e. spheres, hemispheres, dumbbells, and pseudopolyhedral forms), either in isolation or in groups (Figs. 3, 4). All of them are typical of bacterial carbonate precipitation. The dependence of the crystal morphology produced by the tested strains on the artificial culture media was difficult to establish since the morphology was quite heterogeneous. Electron microscopy was used to verify that the calcium carbonate bioliths produced by the bacteria showed a significant quantity of cell marks inside the mass as well as on the surface. This fact confirms that they are formed by the accumulation of calcified organisms. These findings have been previously reported by other authors (Parraga et al. 2004; Rivadeneyra et al. 1998, 2004, 2006a). The observation with FESEM shows mineralized cells defined by rounded cells to Ca-carbonate nanoparticles. Similar nanoparticles have also been found in other bacterial $\mathrm{Ca}-\mathrm{Mg}$ carbonate precipitates, called "nanoglobules" (Aloisi et al. 2006; Sánchez-Román et al. 2008). Sánchez-Navas et al. (2009) interpreted them as the nanocrystalline building units that form bacterially precipitated carbonate mesocrystals.

In the case of actinomycetes, these cell marks are not always present. The microscopical observation of the plates shows that the majority of spherulites are not only in the 
bacterial mass but also nearby the colonies. This result indicates that these spherulites were not formed by the aggregation of bacteria, and in those cases, Actinobacteria only contributed to this formation by changing the media as a consequence of their metabolic activity.

The samples of carbonates also showed precipitation of calcium phosphate and small amounts of amorphous minerals. Rivadeneyra et al. (2010) described the precipitation of carbonates in C. marismortui, beginning with the early formation of amorphous calcium phosphate nanoglobules. During the formation and maturation of the spherulites, these nanoglobules were transformed into amorphous calcium carbonate, which gradually reached higher crystallinity to finally become aragonite. Based on this, in our opinion, the poorly crystalline calcium phosphates and small amounts of amorphous calcium phosphate observed in our precipitates (WWC1, WWC2 and WWC3) may correspond to stages previous to the precipitation of calcium carbonate. The spherulites produced by actinomycetes often comprise calcified filaments on their surface. The microanalysis (Fig. 5) showed a higher percentage of calcium phosphates, a fact which leads us to believe that these filaments may be at an earlier stage of the crystallization process, and confirms that the calcium phosphate may be the precursor of the carbonate. Our findings support the existence of this process, and also indicate that this process is not unique to C. marismortui, but may be a more widespread type of precipitation.

In conclusion, all the results of this study, which is limited to cultibable bacteria, confirm that bacterial activity has an importance role in the formation of calcium carbonate studied in vitro, and that consequently, this is a biomineralization process. The formation of calcium carbonate by microorganisms isolated from domestic wastewater is mainly calcite and vaterite in artificial media, which contains a high concentration of calcium and metabolizable organic matter. However, for the study of calcium carbonate precipitation by bacteria from domestic wastewaters, it is advisable not to use media derived from the wastewater itself since environmental conditions do not create the optimal circumstances for the precipitation of minerals.

Acknowledgments We would like to thank A. González, and I. Guerra from the CIC-University of Granada, for their help during the FESEM and SEM research. This study was carried out as part of the project $\mathrm{CO} 2$ SolStock-Biobased geological CO2 storage funded by the European Commission (7th Framework Programme) (FP7-ENERGY2008-FET).

\section{References}

Aloisi G, Gloter A, Krüger M, Wallman K, Guyot F, Zuddas P (2006) Nucleation of calcium carbonate on bacterial nanoglobules. Geology 34:1017-1020
Altschul SF, Madden TL, Schäffer AA, Zhang J, Zhang Z, Miller W, Lipman DJ (1997) Gapped BLAST and PSI-BLAST: a new generation of protein database search programs. Nucleic Acids Res 25:3389-3402

Beveridge TJ, Fyfe WS (1985) Metal fixation by bacterial cell walls. Can J Earth Sci 22:1892-1898

Clesceri LS, Greenberg AE, Eaton AD (2001) Standard methods for the examination of water and wastewaters, 20th edn. American Public Health Association, Washington DC (APHA)

Cortes-Lorenzo C, Molina-Muñoz ML, Gomez-Villalba B, Vilchez R, Ramos A, Rodelas B, Hontoria E, Gonzalez-Lopez J (2006) Analysis of community composition of biofilms in a submerged filter system for the removal of ammonia and phenol from industrial wastewater. Biochem Soc Trans 34:165-168

Delgado G, Delgado R, Parraga J, Rivadeneyra MA, Aranda V (2008) Precipitation of carbonates and phosphates by bacteria in extract solutions from a semi-arid saline soil. Influence of $\mathrm{Ca}^{2+}$ and $\mathrm{Mg}^{2+}$ concentrations and $\mathrm{Mg}^{2+} / \mathrm{Ca}^{2+}$ molar ratio in biomineralization. Geomicrobiol J 25:1-13

Dove PM, de Yoreo JJ, Weiner S (2003) Biomineralization. Reviews in Mineralogy and Geochemistry 54. Mineralogical Society of America Geochemical Society, Washington

Ehrlich HL (2002) Geomicrobiology, 4th edn. Marcel Dekker, New York

Hammes F, Verstraete W (2002) Key roles of pH and calcium metabolism in microbial carbonate precipitation. Rev Environ Sci Biotechnol 1:3-7

Hammes F, Seka A, de Knijf S, Verstraete W (2003) A novel approach to calcium removal from calcium-rich industrial wastewater. Water Res 37:699-704

Jeanmougin F, Thompson JD, Gouy M, Higgins DG, Gibson TJ (1998) Multiple sequence alignment with Clustal X. Trends Biochem Sci 23:403-405

Jenkins D, Richard MG, Daigger GT (1993) Manual on the causes and control of activated sludge bulking and foaming, 2nd edn. Lewis Publishers, New York, p 193

Lowenstam HA, Weiner S (1989) On Biomineralization. Oxford University Press, Oxford

Martín JD (2004) Using XPowder-a software package for powder X-ray diffraction analysis. http://www.xpowder.com. D.L. GR1001/04. ISBN: 84-609-1497-6, 105 p. Spain

Molina-Muñoz M, Poyatos JM, Vilchez R, Hontoria E, Rodelas B, Gonzalez-Lopez J (2007) Effect of the concentration of suspended solids on the enzymatic activities and biodiversity of a submerged membrane bioreactor for aerobic treatment of domestic wastewater. Appl Microbiol Biotechnol 73:1441-1451

Muyzer G (1999) DGGE/TGEE a method for identifying genes from natural ecosystems. Curr Opin Microbiol 2:317-322

Neefs JM, Van de Peer Y, Hendriks L, Wachter R (1990) Compilation of small ribosomal subunit RNA sequences. Nucleic Acids Res 18:2237-2317

Parraga J, Rivadeneyra MA, Martín-García JM, Delgado R, Delgado G (2004) Precipitation of carbonates by bacteria from a saline soil, in natural and artificial soil extracts. Geomicrobiol J 21:55-66

Rivadeneyra MA, Delgado G, Ramos-Cormenzana A, Delgado R (1998) Biomineralization of carbonates by Halomonas eurihalina in solid and liquid media with different salinities: crystal formation sequence. Res Microbiol 149:277-286

Rivadeneyra MA, Delgado G, Soriano M, Ramos-Cormenzana A, Delgado R (1999) Biomineralization of carbonates by Marinococcus albus and Marinococcus halophilus isolated from the Salar de Atacama (Chile). Curr Microbiol 39:53-57

Rivadeneyra MA, Delgado G, Soriano M, Ramos-Cormenzana A, Delgado R (2000) Precipitation of carbonates by Nesterenkonia halobia in liquid media. Chemosphere 41:617-624 
Rivadeneyra MA, Párraga J, Delgado R, Ramos-Cormenzana A, Delgado G (2004) Biomineralization of carbonates by Halobacillus trueperi in solid and liquid media with different salinities. FEMS Microbiol Ecol 48:39-46

Rivadeneyra MA, Martín-Algarra A, Sánchez-Navas A, MartínRamos D (2006a) Carbonate and phosphate precipitation by Chromohalobacter marismortui. Geomicrobiol J 23:1-13

Rivadeneyra MA, Delgado R, Parraga J, Ramos-Cormenzana A, Delgado G (2006b) Precipitation of minerals by 22 species of moderately halophilic bacteria in artificial marine salts media: influence of salt concentration. Folia Microbiol 51:445-453

Rivadeneyra MA, Martín-Algarra A, Sánchez-Román M, SánchezNavas A, Martín-Ramos D (2010) Amorphous caphosphate precursors for Ca-carbonate biominerals mediated by Chromohalobacter marismortui. ISME J. doi:10.1038/ismej.2010.17

Sánchez-Navas A, Martín-Algarra A, Rivadeneyra MA, Melchor S, Martín-Ramos JD (2009) Crystal-growth behavior Ca-Mg carbonate bacterial spherulites. Cryst Growth Des 9:2690-2699

Sánchez-Román M, Rivadeneyra MA, Vasconcelos C, McKenzie JA (2007) Biomineralization of carbonate and phosphate by halophilic bacteria: influence of $\mathrm{Ca} 2+$ and $\mathrm{Mg} 2+$ ions. FEMS Microbiol Ecol 61:273-281

Sánchez-Román M, Vasconcelos C, Schmid T, Dittrich M, McKenzie JA, Zenobi R, Rivadeneyra MA (2008) Aerobic microbial dolomite at the nanometer scale: implications for the geologic record. Geology 36:879-882

Straful I, Scrimshaw MD, Lester JN (2001) Conditions influencing the precipitation of magnesium ammonium phosphate. Water Res 35:4191-4199

van Lith Y, Warthmann R, Vasconcelos C, McKenzie JA (2003) Microbial fossilization in carbonate sediments: a result of the bacterial surface involvement in carbonate precipitation. Sedimentology 50:237-245

Vinuesa P, Rademaker JL, Bruijn W, Werner D (1998) Genotypic characterization of Bradyrhizobium strains nodulating endemic woody legumes of the Canary Islands by PCR-restriction fragment length polymorphism analysis of genes encoding $16 \mathrm{~S}$ rRNA (16S rDNA) and 16S-23S rDNA intergenic spacers, repetitive extragenic palindromic PCR genomic fingerprinting and partial 16S rDNA sequencing. Appl Environ Microbiol 64:2096-2104

Wagner M, Loy A, Nogerira R, Purkhold U, Lee N, Daims H (2002) Microbial community composition and function in wastewater treatment plant. Antonie Van Leeuwenhoek 81:665-680

Weisburg WG, Barns SM, Pelletier DA, Lane DJ (1991) 16S ribosomal DNA amplification for phylogenetic study. J Bacteriol 173(2):697-703 